\title{
Integrative Review about Learning of the Elderly Person in Health Care Promotion
}

\author{
Maria Helena Gehlen"1, Claus Dieter Stobäus² \\ ${ }^{1}$ Postgraduate Program in Biomedical Gerothology, Pontifical Catholic University of Rio Grande do Sul, Porto Alegre, Brazil \\ ${ }^{2}$ Postgraduate Program in Education and in Biomedical Gerontology, Pontifical Catholic University of Rio Grande do Sul, \\ Porto Alegre, Brazil \\ Email: stobaus@pucrs.br
}

How to cite this paper: Gehlen, M. H., \& Stobäus, C. D. (2019). Integrative Review about Learning of the Elderly Person in Health Care Promotion. Creative Education, 10, 308-318.

https://doi.org/10.4236/ce.2019.102025

Received: January 8, 2019

Accepted: February 17, 2019

Published: February 20, 2019

Copyright (c) 2019 by author(s) and Scientific Research Publishing Inc. This work is licensed under the Creative Commons Attribution International License (CC BY 4.0).

http://creativecommons.org/licenses/by/4.0/

(c) (i) Open Access

\begin{abstract}
Human aging is a complex and global phenomenon. It is necessary to care for and educate both those who teach (professionals, caregivers) and those who are (self)educated in order to maintain their vitality, functionality and independence, according to their care needs, in their daily life. In this study we aimed to know the scientific productions that work themes related to about how the elderly use learning strategies to learn how to take care of their own health. For this purpose, an Integrative Review of Literature was carried out, consisting of the following steps: identification of the problem or guiding question, establishment of descriptors, temporal cut-off, sampling search in the literature, data collection, analysis of included studies, results and discussion of content synthesis. From the synthesis of the content of the articles, it was possible to carry out the analysis of the productions and to construct a thematic axis as a guide for discussion, considering that, in order to occur learning, it is necessary to value the dialogue, the knowledge, the exchange of experiences and information with the elderly, making it possible to consolidate a process of critical, meaningful and emancipatory teaching, as a way of empowering autonomy, independence for self-care, and self-control of health and maintenance of functional and participatory capacity.
\end{abstract}

\section{Keywords}

Learning, Teaching, Elderly, Integrative Review, Heath Care

\section{Introduction}

The present work is a result of debates of ideas among the authors, in the search for a Reference for Gehlens' Doctoral Thesis, as thematic on "the processes of teaching and learning: the educational dimension in the promotion of the health 
care of the old person", in the Postgraduate Program in Biomedical Gerontology of the Faculty of Medicine of PUCRS, in Porto Alegre-RS, Brazil.

Human aging is a global and complex phenomenon, for which there are necessary to have public policies, preparation of the society and for schools and universities to invest more in the preparation of the citizens to more understanding and pay more attention to human development and many aspects involved on it. According to the Pan American Health Organization, individual aging is a sequential, cumulative, irreversible, universal and non-pathological process of deterioration of the mature organism. This process, a characteristic of all members of the species, occurs in such a way that time makes the organism less able to cope with the stress of the environment and thus increases the possibility of death, according to OPAS/PAHO (2009).

The Brazilian Institute of Geography and Statistics (Brasil, IBGE, 2015) considers the population growth of the elderly in Brazil as one of the largest in the world, and by the year 2022 there will be 1.0 million elderly people.

In this sense, population aging is considered a public health problem, especially when longevity correlates with institutionalization or with chronic and chronic diseases that promote social remoteness and increase hospital admissions, morbidities and mortality (Brasil, Ministério da Saúde, 2017).

In this sense, it is necessary to care for and educate the elderly in maintaining their vitality, functionality and independence, according to their daily care and learning needs.

\section{Theoretical Reference}

Geography and Statistics (Brasil, IBGE, 2015) considers the population growth of the elderly in Brazil as one of the largest in the world, and by the year 2022 there will be 1.0 million elderly people. In this sense, population aging is now considered a public health problem, especially when longevity correlates with institutionalization or with chronic and chronic diseases that promote social remoteness and increase hospital admissions, morbidities and mortality (Brasil, Ministério da Saúde, 2017).

The longevity in institutionalization, especially in a long-term institution or in a hospital, causes changes in the daily life of the elderly person, since it makes them dependent on health care due to the fragility that comes from the loss of functionality, which also compromises the desire to learn how to provide care about their daily health.

According to Moraes (2012), from the index proposed by Katz in 1963, it was possible to stratify the individuals according to the degree of dependence in daily life activities (ADL) related to self-care.

According to this index, the elderly were classified as independent and dependent on ADL, both of which present complexities related to culture and learning, with the need for geriatric-gerontological follow-up.

According to Moraes (2009), aging without any chronic disease is more an 
exception than a rule, and individuals with the same clinical diagnosis may have different functional capacity from one another. The importance of caring and educating for the maintenance of functionality and well-being in the elderly person's life is highlighted, since they are complementary and configure their autonomy, as well as the capacity to make decisions and to have command over actions, in order to establish and follow their own convictions.

With regard to independence, the above-mentioned author understands it as the capacity to do something with one's own means and as the capacity to take care of oneself and of one's own life. However, although there is a relational interconnection between the concepts of "independence" and "autonomy", they are not synonyms, but have different meanings.

That is, people with physical dependence are able to elect activities; others have the physical conditions to perform certain daily tasks, but they do not have the decision to perform them. In this sense, the loss of independence is not always associated with the loss of autonomy, since an elderly person with loss of the ability to wander can learn to manage their life with autonomy and social participation.

It should be emphasized that independence and autonomy are closely related to the integrated and harmonious functioning of the systems of cognition, humor, behavior, mobility and communication. For this reason, Ramos (2003) and Moraes (2012) consider functionality as the basis of the overall concept of health promotion of the elderly, while functional decline is understood as the loss of autonomy and/or independence, by restricting the social participation of the individual.

Moraes \& Moraes (2016) mention that impairment of functional systems and/or geriatric syndromes in the daily life of the elderly, such as cognitive impairment, postural instability, immobility, sphincter incontinence, communicative incapacity, family insufficiency and iatrogenesis cause loss of independence and autonomy and, consequently, generate the need for long-term care, with a differentiated management performed by health professionals or family/caregivers, as well as generating the need for health education.

Elderly health education in the aging process assists in the readjustment of daily life activities (ADLs), instrumental activities of daily living (AIVDs) and advanced activities of daily living (AAVD). The AIVDs relate to the condition of performing tasks necessary for home care or domestic activities, while the AAVDs refer to productive, recreational and social activities (Moraes \& Moraes, 2016).

In this scenario, the aging process of the individual is not synonymous with incapacity and dependence, but with greater vulnerability, and the World Health Organization (OMS, 2016), in its Agen-friendly program, emphasizes that countries must have an effective system health care, protection, care, maintenance and promotion of health education through prevention, treatment, rehabilitation of diseases and social reintegration, in order to meet the individual needs of the 
aging population.

In addition to ensuring infrastructure, countries must provide and develop adequate financial and environmental conditions in support of active aging, which is not restricted to participation in physical activity programs or integration of the workforce, but also includes the continued participation of the person elderly in social, educational, spiritual, cultural and civil matters.

The need to learn the elderly in the geriatric-gerontological care is therefore perceived, since caring and educating are interconnected processes and, when neglected, trigger successive iatrogenies, especially if coupled with family insufficiency, characterized by lack of financial, intellectual and organizational aspects of the family in promoting the daily life care of the elderly.

With these considerations, the research question is presented: what scientific productions evidence the learning of the elderly with regard to the care of their health in a qualitative way (Minayo, 2012)?

\section{Method and Materials}

Rother (2007) proposed the construction of an integrative literature review, related to the object of the study, consisting of the following steps: identification of the problem or guiding question, establishment of descriptors, temporal clipping, search of the sample in the literature and data collection, analysis of included studies, results and discussion of content synthesis.

In order to do so, the articles published and indexed in the Virtual Health Library (VHL), electronic databases of the Latin American and Caribbean Literature in Health Sciences (LILACS), Nursing Database (BDENF) and in the Medical Literature Analysis and Retrieve System Online (MEDLINE). The descriptors were established and classified in Health Sciences (DeCS) and refined using the Boolean operator "and”.

Regarding the evaluation of the level of evidence, the studies were classified according to the definition of Melnyk \& Fineout-Overholt (2005) as level V. The temporal cut of the articles was from 2000 to October 2018, considering those published in Portuguese, Spanish and English. The strategy used to identify the articles can be seen in Figure 1, represented by the sample selection flowchart.

Thus, we obtained the amount of 13 findings to compose the study analysis corpus.

In order to facilitate the understanding of the findings of the scientific literature and its discussion, a table called Integrative Analysis References of the articles was elaborated, being included in Table 1 (we emphasize that these are not in the References at the end of the text).

\section{Results and Discussion}

It was possible to consider that the authors of A1 emphasize old age as being heterogeneous, emphasizing the importance of activities for a healthy aging, in which the acquisition of new learning is an important task to improve the cogni- 
tive capacities and favor the network of social support of the elderly. They emphasized, therefore, the importance of education for a healthy old age, considering the process of lifelong learning.

The aging process in its uniqueness demands the learning of the elderly person, in the promotion of their health, as it stimulates them to re-adjust their daily environment, according to their particularities. In this sense, the teaching developed by health professionals reveals itself as an effective process of the educational dimension.

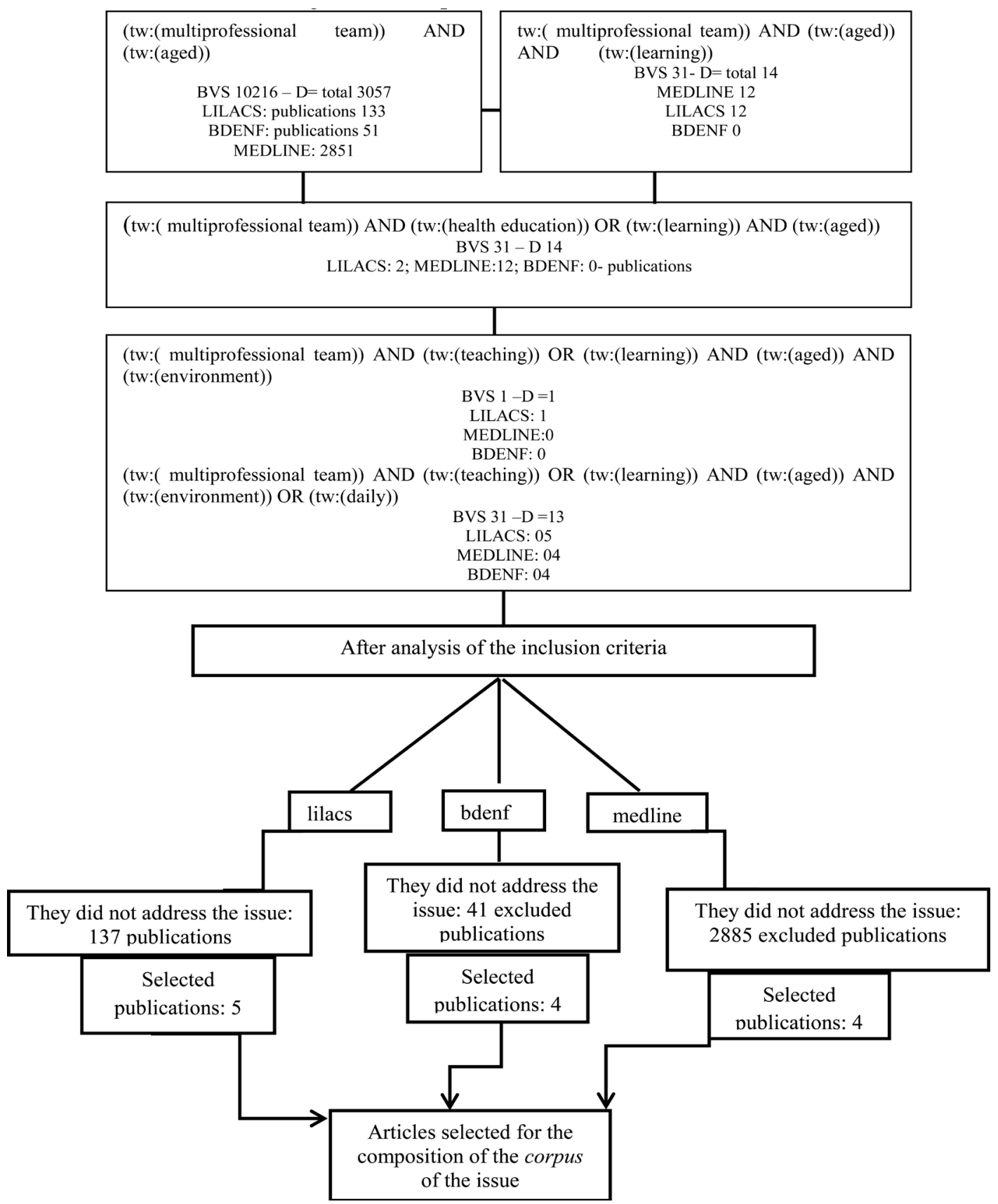

Source: authored by the author.

Figure 1. Sample selection flowchart. 
Table 1. References of the integrative analysis of the articles.

A1 SCORALICK-LEMPKE, N. N.; BARBOSA, G. J. A. Educação e envelhecimento: contribuições da perspectiva Life-Span. Estudos de Psicologia I, Campinas I 29 (Supl.) I 647s-655s I, out./dez. 2012.

A2 VAGETTI, G. C.; ANDRADE, G. O. Fatores influentes sobre o processo de ensino-aprendizagem na educação física para idosos. Acta Sci. Health Sci. Maringá, v. 28, n. 1, p. 77-86, 2006.

SOUSA, S. M. E.; OLIVEIRA, C. C. M. Viver a (e para) aprender: uma intervenção-ação para a promoção do envelhecimento ativo, Rev. Bras. Geriatr. Gerontol, Rio de Janeiro, v. 18, n. 2, p. 405-415, 2015.

MENEZES, Z. C. A.; NASCIMENTO, E. Estudo Longitudinal das Habilidades Intelectuais de Idosos Avaliados com a WAIS-III, Psicologia: Reflexão e Crítica, v. 24, n. 3, p. 419-428, 2011. Disponível em: http://www.scielo.br/prc

ROCHA, S. L.; SOUZA, S. M. E.; ROSENDO, A. C. Necessidades humanas básicas e dependência de cuidados de enfermagem de idosos

COSTA, C. E.; NAKATANI, K. Y. A.; BACHION, M. M. Capacidade de idosos da comunidade para desenvolver Atividades de Vida Diária e Atividades Instrumentais de Vida Diária. Acta Paul Enferm, v. 19, n. 1, p. 43-35, 2006.

BESSE, M.; OLIVEIRA, O. C. L.; LEMOS, D. N. A Equipe Multiprofissional em Gerontologia e a Produção do Cuidado: um estudo de caso. Revista Kairós Gerontologia, São Paulo (SP), Brasil: FACHS/NEPE/PEPGG/PUC-SP. v. 17, n. 2, p. 205-222, 2014.

NICOLATO, F. V. N.; COUTO, M. A.; CASTRO, B. A. E. Capacidade de autocuidado de idosos atendidos pela consulta de enfermagem na atenção secundária à saúde, Enferm. Cent. O. Min. v. 6, n. 2, p. 2199-2211, mai./ago. 2016.

LUCENA, A. L. R. de et al. Ensinando e aprendendo com idosos: relato de experiência, J. res.: fundam. care. Online, v. 8, n. 2, p. 4131-4141, abr./jun. 2016.

A10 AMTHAUER, C.; FALK, W. J. Discursos dos profissionais de saúde da família na ótica da assistência à saúde do idoso, J. res.: fundam. care. Online, v. 9, n. 1, p. 99-105, jan. /mar. 2017.

VIEIRA, D. C. D. et al. Percepções de usuários da estratégia de saúde da família sobre saúde, prevenção e autocuidado. J Nurs UFPE on line, Recife, v. 10, n. 2, p. 413-418, fev. 2016.

A12 MEDEIROS, V. D. et al. A percepção do idoso sobre a velhice. Rev enferm UFPE on line, Recife, v. 10, n. 10, p. 3851-2859, out. 2016.

A13 CLARES, B. W. J.; BORGES, L. C.; FREITAS, C. M. Idosos institucionalizados: proposta educativa na perspectiva freireana. Rev enferm UFPE on line, Recife, v. 11(Supl. 2), p. 1073-1077, fev. 2017.

Source: authored by the author.

The assessment of the learning needs of the elderly, in geriatric and gerontological care, through the teaching of health professionals is considered, in health education, as an affective and effective foundation for health promotion of the elderly.

For Arantes (2007), Health Education should consider the values of daily life, the factors related to the diseases, the willingness to teach and the readiness to learn. The binomial of Education in values refers to the complex and controversial relations of the multidimensional human being with himself and the society in which he lives, for it is the appropriation of culture that enables individuals to think, judge, criticize, elaborate, recognize, so learn.

According to A2, the professionals who work with the elderly in their different areas need a training focused on the necessary care with this population, that is, such workers must work on gerontology both in the technical aspects of the movement and in the broader factors that involve teaching and learning.

In this sense, the learning of the elderly through the teaching of health profes- 
sionals is an educational dimension that can be systematized and linked to the multidimensional model of health of the elderly, regarding more assistance, guidance, supervision, referral and follow-up in the promotion and protection of their health.

In the study of $\mathrm{A} 3$, developed in the district of Braga, in Portugal, it was argued that group activities with the elderly, when pleasant, make it possible to acquire new knowledge, which helps in daily life, increasing the quality of life, the elderly autonomous, participatory and active, because they are in constant learning.

Data from the A4 survey indicate that aging, although healthy, leads to a normal decline in intellectual performance. However, the study showed that young adults may gain gains in their vulnerable skills, such as perceptual organization, learning, memory, problem solving, and processing speed, although their declines are considered. Therefore, variations to learn are not characterized by a generalized decline pattern, i.e. they do not occur in all abilities and vary with age.

These data share with A5, where the basic human needs of institutionalized elderly people refer to body care, health education, locomotion, and elimination and mobility. This is due to a degree of dependence on nursing care, since many elderly people were partially dependent, so the results allowed a better understanding of the real needs demanded by the elderly.

Moraes (2012) mentions that in the aging process, from the age of 80 , some degree of physiological commitment is expected, in the ability to perform ABVD. But not in the capacity to relearn, since the intensity and frequency of the impairment are depending on the general health conditions, throughout life, and on the way of life of the elderly in their socio-economic-historical-cultural context.

In the author's line, aging is closely associated with the embrittlement process, but there is no direct cause-and-effect relationship, since it does not follow a homogeneous pattern of evolution, justifying the heterogeneity present in elderly individuals of the same age. Therefore, age alone is not a predictor of frailty and learning deficit.

According to A6, in the face of population aging, the goal in health care is no longer to prolong life, but mainly to maintain the functional capacity of the individual, so that he remains autonomous and independent for the longest possible time. For this to happen, the health system needs to ensure universal access to progressive health care and public policies should emphasize health promotion and disease prevention.

The results of $\mathrm{A} 7$ article are in line with this assertion, since they defend the production of health care for the elderly by a multi-professional team. Also emphasize interdisciplinarity as a fundamental means in promoting education not only with technical care but also with lay care, carried out at home, ensuring a care plan and coping with various difficulties resulting from the scarcity of human resources, equipment and supplies. 
According to Ramos (2003), the majority of the elderly have diseases or organic dysfunctions that, in most cases, are not associated with the limitation of activities or the restriction of social participation. The person is considered healthy when he is able to perform daily tasks independently and autonomously, even in the presence of diseases, so he is able to learn.

In A8 it was stated that the elderly person demonstrates behavior of seeking care in secondary care, with the goal of learning to perform general and therapeutic self-care. The nursing intervention used in this level of attention was the one of support to the education, standing out the actions of orientation with the teaching of therapeutic self-care. In addition, the authors considered the elderly independent, as those who seek the most care at the outpatient level. Also, they observed the predominance of the nursing system in the educational support of the education on the measures of therapeutic self-care, prevailing the offer of actions of health promotion and prevention of diseases, with a view to valorizing the independence, autonomy and self-care of the elderly.

The production of A9 reports on health education practices, which encourage the adoption of preventive self-care measures regarding the health of the elderly in situations of multiple vulnerabilities and help health professionals to build new subsidies and ideas for care, a reflection on the uniqueness of the elderly and contributing to the effective assistance to longevity with quality of life.

According to Moraes \& Moraes (2016), the interdisciplinary work in Gerontology, in the multidimensional model for the promotion of the health of the elderly, transcends the limits of the disciplines and aggregates the active participation of the elderly, family, society and the State, demands of the aging process.

According to A10, the practices carried out by the professionals of the Family Health Strategy (ESF) with the elderly attending a Basic Health Unit are related to the aging process, being the role of the health professional to ensure comprehensive care for the elderly, with a dignified and humanized service, understanding it in its totality.

In A11, on the other hand, when analyzing the perceptions of users of a Family Health Strategy regarding the understanding of the concepts of health, disease prevention and self-care, the need to promote health in several aspects was evidenced: habits of health, work environment qualification, housing and community participation.

This action is intimately interconnected with the educational dimensions of caring, teaching and learning, since there are possibilities to develop gerontological interventions in prevention, healing, control, recovery or comfort, depending on the acute or chronic condition of health and the degree of functionality of the elderly, because they have as purpose the definition of functional and clinical diagnoses, which are essential to elaborate and plan the interdisciplinary care plan.

In describing the elderly's perception of aging and the aging process, according to A12, old age was a harbinger of dependence, loneliness and incapacity for work, and it is necessary to appreciate these perceptions with a different look at 
their demands, with educational strategies for your expectations.

De Lira, da Silva Santos, Ribeiro \& Stobäus (2017), related to empowerment of elderly, especially in terms of popular education related to health promotion in peripheral villages in major cities, must receive more supports from government, as well as non-governmental organizations, in the direction to improve more knowledge, skills and attitudes, for acquire more autonomy.

Based on the ideas of A13, it was possible to reflect on the potentialities and limitations of health education practices, aimed at elderly people living in long-term institutions, through an educational proposal regarding knowledge and cultural values.

According to Bastable (2010), teaching is a complex process in which there is help to learn new behaviors, more related to health and the maintenance of independence in everyday life. As a result of experience, there is a relatively long-lasting change in mental process and emotional and/or behavioral functioning.

The author describes learning as a dynamic and permanent process by which individuals acquire new knowledge, new skills and modify their thoughts, feelings, attitudes and actions. In this way, individuals adapt to the different demands, circumstances and clinical conditions, being, therefore, the essential learning for health care.

As we sad (Mosquera \& Stobäus, 2016: pp. 1264-1265),

Thus, both health aspects such as the disease are contemplated as an important dialectic to the development of the personality of a person to his late adulthood, through these social representations that are configured in ways J. J. M. Mosquera, C. D. Stobäus 1265 of thinking and acting, have emotions and know manage them in a society so quick adjustments and continuous changes. So, we can see that human existence would be in fact a construction that relies heavily on our senses, values and meanings that represent the world and we develop.

However, in the operationalization of health care to the elderly, it is often perceived that there may be a certain "negligence" of the perception and use of elements such as Health Education. Since the teaching is not always effective and is not completely performed, especially in geriatric care, there are often only technical interventions related to multimorbidity, polypharmacy, inapparent disease, functional loss, associated diseases or the presence of geriatric syndromes.

\section{Final Considerations}

By knowing the scientific productions evidencing the learning of the elderly and learn more about how to take care of their health, it is considered that the promotion of health in the context of human aging is a therapeutic process. Must be expanded and articulated to the educational, clinical, functional, socio-environmental dimensions and psychosocial factors, being an important ally in the reorganization of the daily life of the elderly, in the maintenance of functionality, and welfare. 
To this end, dialogue, knowledge, exchange of experiences and information with the elderly should be valued, making it possible to consolidate a process of critical, meaningful and emancipatory teaching as a way of empowering autonomy, independence for self-care, self-control of maintaining functional and participatory capacity.

Autonomy and independence rescue the importance of the integrality of the concept of health in the elderly, which makes multidimensionality present in every evaluation. In this sense, learning in the promotion of functionality helps the elderly in their decision making with autonomy, making them responsible. Also guarantees the respect and freedom to expose their needs in the reorganization of their daily life, since the educational dimension is a dialogical process that enables new learning, behavior change in favor of their well-being, to a better quality of life, with therapeutics, management and management of care and self-care.

Thus, from the synthesis and theoretical integration, it is possible to perceive the need for evidence regarding the publications about learning, in its relations with the development of the teaching process of health professionals. However, regarding the consideration of health education, the constructs constitute a relational factor for the monitoring, treatment, attention, promotion and protection of the health of the elderly person.

Therefore, it is necessary to reiterate the need for professionals who are in contact through multidisciplinary and interdisciplinary teams, as well as caregivers and patients themselves, that they should be more attentive and aware of continuous training, in terms of the teaching and learning aspects involved. And in terms of (re)knowledge of concepts, in terms of skills (related practices), and in terms of more proactive and comprehensive attitudes, in what is widely denominated teaching and corresponding learning in the fields of Education and of health.

This study was financed in part by the Coordenação de Aperfeiçoamento de Pessoal de Nivel Superior-Brasil (CAPES)_Finance Code 001.

\section{Conflicts of Interest}

The authors declare no conflicts of interest regarding the publication of this paper.

\section{References}

Arantes, V. A. (2007). Educação e valores [Education and Values]. São Paulo: Summus.

Bastable, S. B. (2010). O Enfermeiro como Educador: Princípios de Ensino-Aprendizagem para a prática de enfermagem [Nursing as an Educator: Teaching-Learning Principles for Nursing Practice] (3rd ed.). Porto Alegre: Artmed.

de Lira, G. A., da Silva Santos, M., Ribeiro, K. S. Q. S., \& Stobäus, C. D. (2017). Elderly Empowerment: Health Promotion in the Perspective of Popular Education in Health. Creative Education, 8, 1111-1123. https://doi.org/10.4236/ce.2017.87080

IBGE (2015). Mudança demográfica no Brasil no início do século XXI: Subsídios para as 
projeções da população [Demographic Change in Brazil at the Beginning of the 21st Century: Subsidies for Population Projections]. Rio de Janeiro: Instituto Brasileiro de Geografia e Estatística.

Melnyk, B. M., \& Fineout-Overholt, E. (2005). Evidence Based Practice in Nursing \& Healthcare. A Guide to Best Practice (pp. 3-24). Philadelphia: Lippincot Williams \& Wilkins.

Minayo, M. C. S. (2012). Análise qualitativa: Teoria, passos e fidedignidade [Qualitative Analysis: Theory, Steps and Reliability]. Revista Ciência e Saúde Coletiva, 17, 621-626. https://doi.org/10.1590/S1413-81232012000300007

Ministério da Saúde (2017). Estratégia para promoção do envelhecimento saudável [Strategy to Promote Healthy Aging]. Brasília.

Moraes, E. N. (2009). Princípios básicos em Geriatria e Gerontologia [Basic Principles in Geriatrics and Gerontology]. Belo Horizonte: Coopmed.

Moraes, E. N. (2012). Atenção à saúde do Idoso: Aspectos Conceituais [Health Care of the Elderly: Conceptual Aspects]. Brasília: Organização Pan-Americana da Saúde.

Moraes, E. N., \& Moraes, F. L. (2016). Coleção Guia de Bolso em Geriatria e Gerontologia: Avaliação multidimensional do Idoso [Handbook Collection in Geriatrics and Gerontology: Multidimensional Assessment of the Elderly] (5th ed.). Belo Horizonte: Folium.

Mosquera, J. J. M., \& Stobäus, C. D. (2016). Healthy Aging: Education, Health, Health Psychology and Leisure. Creative Education, 7, 1261-1269.

https://doi.org/10.4236/ce.2016.79133

OMS (2016). Ageing and Life Course. Organização Mundial de Saúde. http://www.who.int-ageing-em

OPAS (2009). Plan de acción sobre la salud de las personas mayores incluido el envejecimiento activo $y$ saludable [Plan of Action on the Health of the Elderly including Active and Healthy Aging]. Washington DC: Organização Pan-Americana da Saúde.

Ramos, L. R. (2003). Fatores determinantes do envelhecimento saudável em idosos residentes em centro urbano: Projeto ediposo [Determinants of Healthy Aging in Elderly People Living in Projeto Epidoso, São Paulo]. Cadernos de Saúde Pública, 19, 793-798. https://doi.org/10.1590/S0102-311X2003000300011

Rother, E. T. (2007). Revisão sistemática x revisão narrativa [Systematic Review vs. Narrative Review]. Revista Acta Paulista de Enfermagem, 20, 1-2.

https://doi.org/10.1590/S0103-21002007000200001 